\title{
Detection of point mutations in $K R A S$ oncogene by real-time PCR-based genotyping assay in GIT diseases
}

\author{
Ugorcakova $\mathrm{J}^{1}$, Hlavaty $\mathrm{T}^{2}$, Novotna $\mathrm{T}^{3}$, Bukovska $\mathrm{G}^{1}$ \\ Institute of Molecular Biology, Slovak Academy of Sciences, Bratislava, Slovakia. jana.ugorcakova@savba.sk
}

\begin{abstract}
Objectives: The determination of gene mutations is important for the diagnosis and prognosis of various gastrointestinal cancers. The aim of our study was to develop a new procedure for the analysis of KRAS gene mutation by application of the real-time PCR method.

Background: The detection process requires discriminate trace amount of mutant allele in a large excess of wild-type DNA in various samples.

Methods: The real-time PCR based technique using hybridization probes for five most frequently KRAS codon 12 mutations and WT specific peptide nucleic acid (PNA) was performed. Our multiplex detection system was tested in various DNA samples (tissue, bile, pancreatic juice) of patients with different diagnoses of gastrointestinal tract disease obtained by endoscopy and ERCP.

Results: We designed and optimized the real-time PCR conditions and tested various amount of PNA in PCR reaction to suppress amplification of the wild-type DNA. We determined the interassay variability of the melting temperatures and the results of mutation testing were confirmed by DNA sequencing with the $100 \%$ accuracy. Incidence of searched mutations was $67.5 \%$ in cohort of 40 patients; for $K R A S^{\mathrm{G} 12 \mathrm{D}}$ it was in $44.4 \%, K R A S^{\mathrm{G} 12 \mathrm{~V}}$ in $22.2 \%, K R A S^{\mathrm{G} 12 \mathrm{~S}}$ in $14.8 \%, K R A S^{\mathrm{G} 12 \mathrm{~A}}$ in $14.8 \%$ and $K R A S^{\mathrm{G} 12 \mathrm{C}}$ in $3.8 \%$. The sensitivity of the assays is $1 \times 10^{-5}$. Conclusions: Advantages of this technique are rapidity, accuracy and it is generally easy to perform. This method can be adapted for synchronic detection of multiple mutations and after readjustment by other type mutation of KRAS gene may serve as useful clinical tool for analyzing point mutations in various clinical samples (Tab. 3, Fig. 3, Ref. 42). Full Text in PDF www.elis.sk.

Key words: colorectal carcinoma, KRAS, codon 12 mutation, pancreatic carcinoma, real-time PCR.
\end{abstract}

The RAS genes encode a family of GTPases that act as the signal switch molecules for many important cellular processes. RAS proteins, which play a key role in cell growth, apoptosis and differentiation, are low molecular weight (21 kD) GTPases, which cycle between the GDP-bound (inactive) and the GTPbound (active) states at the plasma membrane. Genetic alterations of $K R A S$ oncogene have a crucial role in pancreatic and colorectal carcinogenesis $(1,2,3)$. The prevalence of KRAS mutations are in pancreatic carcinoma $75-100 \%$, in colorectal carcinoma (CRC) $40-50 \%$, in lung carcinoma $15-40 \%$. KRAS point mutations mostly occur in codons 12,13 and 61 . The most frequent type of $K R A S$ mutations in CRC are GGT $>$ GAT $\left(K R A S^{\mathrm{G} 12 \mathrm{D}}\right.$, Asp) in 37 to $54 \%$, GGT $>$ GTT $\left(K R A S^{\mathrm{G} 12 \mathrm{~V}}\right.$, Val $)$ in 28 to $30 \%$, GGT $>$ AGT

${ }^{1}$ Institute of Molecular Biology, Slovak Academy of Sciences, Bratislava, Slovakia, ${ }^{2}$ Department of Internal Medicine, Faculty Hospital Ruzinov, Comenius University, Bratislava, Slovakia, and ${ }^{3}$ Department of Gastroenterology, Faculty Hospital St. Cyril and Method's, Comenius University, Bratislava, Slovakia

Address for correspondence: J. Ugorcakova, Institute of Molecular Biology, Slovak Academy of Sciences, Dubravska cesta 21, SK-845 51 Bratislava, Slovakia.

Phone: +421 259307440

Acknowledgements: This study was supported by VEGA grant 2/7160/27 from Slovak Academy of Sciences and APVV-0354-07 grant from the Slovak Research and Development Agency.
$\left(K R A S^{\mathrm{G} 12 \mathrm{~S}}, \mathrm{Ser}\right)$ in 11 to $15 \%$, GGT>TGT $\left(K R A S^{\mathrm{G} 12 \mathrm{C}}, \mathrm{Cys}\right)$ in 7 to $20 \%$, GGT $>$ GCT $\left(K R A S^{\mathrm{G} 12 \mathrm{~A}}\right.$, Ala $)$ in 4 to $10 \%$, GGT $>\mathrm{CGT}$ $\left(K R A S^{\mathrm{G} 12 \mathrm{R}}, \mathrm{Arg}\right)$ in 2 to $7 \%,(4,5)$. Recent evidences suggest that different mutations in KRAS have different biological consequences in vivo (6). In addition, although $K R A S^{\mathrm{G} 12 \mathrm{D}}$ seems to be more frequent compared to $K R A S^{\mathrm{G} 12 \mathrm{~V}}$ in colon cancer and has been associated with more aggressive colorectal carcinomas and higher mortality than other codon 12 or 13 mutations $(7,8,9)$. It follows that the type of $K R A S$ mutations can influence the survival rate of $C R C$ patients.

Despite of some problems with sampling (tissue availability, tissue release and shipment, and results feedback) it was shown that the KRAS mutation screening is clinically relevant for detection of CRC and pancreatic cancer and for treatment response (10).

$K R A S$ oncogene was described more than 25 years ago. The development of effective tools for early detection could play a key role in reducing the mortality of this disease. This type of mutation is detected in early stadium where only few evident symptoms are present and therefore more hope for curability exists (11). There are various mostly PCR-based techniques for detection of KRAS gene point mutation. The problem of using somatic mutations as markers of malignancy is minimal amounts of mutant DNA in a large excess of wild-type DNA containing in clinical samples. Variety of technologies based on allele discrimination strategies have been applied in the identification of 
point mutations, such as oligonucleotide ligation $(12,13)$, PCR enriched enzymatic cleavage $(14,15,16)$, allele-specific oligonucleotide hybridization (17) and integration of allele-specific oligonucleotide ligation assay (OLA) with magnetic beads based on electrochemiluminescence (18). Pyrosequencing methods based on chemiluminescence $(19,20)$ and primer extension (21) was also described. However, each of these methods has some disadvantages. Many of them are either technically very complicated, expensive or time consuming and thus they are not suitable for routine clinical diagnostic process.

Real-time PCR has attractive features for tumor profiling in the clinical laboratory (22). The novel method was introduced recently for genotyping of $K R A S$ gene $(23,24,25,26)$. The are several advantages of real-time PCR techniques: PCR is not influenced by non-specific amplification, there is no post-PCR processing of products (high throughput, low contamination risk), amplification can be monitored in real-time, ultra-rapid cycling (30 minutes to 2 hours), confirmation of specific amplification by melting point analysis. These methods are more specific, sensitive and reproducible, not much more expensive than conventional PCR (except equipment cost). The mutation-sensitive hybridization profile of peptide nucleic acids (PNAs) has been exploited to design PCRclamping protocols (27). PNAs are non-extendable oligonucleotides, in which the ribose-phosphate backbone is replaced by 2-aminoethyl glycine units linked by amide bonds. PNA oligomers suppress amplification of the wild-type sequence confined by pair DNA oligonucleotide primers (competitive clamping) because they are no substrate for DNA polymerases. For this reason, all alleles with single base changes can be easily distinguished from wild-type by melting peak analysis. The PNA-clamped probe assay is more sensitive than direct sequencing with the ability to detect mutations in samples containing less than $1 \%$ mutant alleles (28).

In our study we present a novel real-time PCR method that is useful to detect simultaneously defined KRAS mutations in various types of clinical samples. In preliminary study, we found mutations in samples of patients with different GIT diagnosis. In our assay we tested only 5 the most frequent codon 12 mutation of $K R A S$ gene. We have improved an assay of hybridization probes by combination of wild-type PNA 15 oligomer to achieve more sensitivity and specificity of detection.
Tab. 1. Patients and incidence of KRAS mutations in DNA samples.

\begin{tabular}{|c|c|c|c|c|c|}
\hline Patient $\mathrm{N}^{\circ}$ & Age & Sex & $\mathrm{Dg}$ & $\begin{array}{l}\text { Type of } \\
\text { sample }\end{array}$ & $\mathrm{Mu}$ \\
\hline 1 & 71 & $M$ & $\mathrm{CPo}$ & $\mathrm{T}$ & $\mathrm{C}$ \\
\hline 2 & 47 & F & CPo & $\mathrm{T}$ & - \\
\hline 3 & 76 & $\mathrm{M}$ & CPo & $\mathrm{T}$ & D \\
\hline 4 & 80 & F & CRC & $\mathrm{T}$ & A \\
\hline 5 & 62 & M & BTC & $\mathrm{Pj}$ & $\mathrm{S}$ \\
\hline 6 & 57 & F & BDS & $\mathrm{Pj}$ & A \\
\hline 7 & 60 & $\mathrm{M}$ & PAC & B & - \\
\hline 8 & 47 & $\mathrm{P}$ & $\mathrm{PC}$ & B & $\mathrm{D}$ \\
\hline 9 & 57 & $\mathrm{M}$ & PAC & B & - \\
\hline 10 & 66 & M & BTC & B & D \\
\hline 11 & 58 & M & PC & B & D \\
\hline 12 & 74 & M & BTC & B & - \\
\hline 13 & 47 & M & BTC & B & $\mathrm{D}$ \\
\hline 14 & 62 & M & $\mathrm{PC}$ & B & - \\
\hline 15 & 65 & M & PAC & B & V \\
\hline 16 & 74 & $\mathrm{~F}$ & BDS & B & V \\
\hline 17 & 83 & F & $\mathrm{PA}$ & B & V \\
\hline 18 & 57 & F & BDS & B & - \\
\hline 19 & 65 & M & BTC & B & $\mathrm{D}$ \\
\hline 20 & 81 & $\mathrm{~F}$ & BDS & B & - \\
\hline 21 & 38 & F & BDS & B & $\mathrm{D}$ \\
\hline 22 & 59 & M & PAC & B & - \\
\hline 23 & 52 & M & $\mathrm{PAC}$ & B & $\mathrm{D}$ \\
\hline 24 & 58 & $\mathrm{~F}$ & PAC & B & $\mathrm{V}$ \\
\hline 25 & 54 & M & $\mathrm{PC}$ & B & $\mathrm{D}$ \\
\hline 26 & 59 & M & PA & B & $\mathrm{S}$ \\
\hline 27 & 52 & $\mathrm{~F}$ & PAC & B & D \\
\hline 28 & 28 & M & PC & B & D \\
\hline 29 & 59 & M & CRC & $\mathrm{T}$ & A \\
\hline 30 & 77 & $\mathrm{~F}$ & CRC & $\mathrm{T}$ & - \\
\hline 31 & 36 & M & PA & B & $\mathrm{S}$ \\
\hline 32 & 63 & $\mathrm{M}$ & PAC & B & V \\
\hline 33 & 54 & M & BDS & B & - \\
\hline 34 & 70 & F & BTC & B & $\mathrm{S}$ \\
\hline 35 & 70 & M & BDS & B & - \\
\hline 36 & 73 & F & BDS & B & - \\
\hline 37 & 64 & M & BTC & B & D \\
\hline 38 & 71 & F & CRC & $\mathrm{T}$ & A \\
\hline 39 & 60 & M & CRC & $\mathrm{T}$ & - \\
\hline 40 & 49 & $\mathrm{~F}$ & PC & $\mathrm{T}$ & V \\
\hline
\end{tabular}

Tab. 2. DNA sequences of primers, PNA oligomer and probes for detecting KRAS mutations.

\begin{tabular}{|c|c|c|}
\hline Reporter Name & Sequence & Reporter Dye \\
\hline Asp Sensor & 705-TTGCCTACGCC ATCAGCTCCAA-p & Red 705 p-phosphate \\
\hline Val Sensor & 705-TTGCCTACGCC AACAGCTCCAA-p & Red 705 p-phosphate \\
\hline Ala Sensor & 705-TTGCCTACGCC AGCAGCTCCAA-p & Red 705 p-phosphate \\
\hline Cys Sensor & 705-TTGCCTACGCC ACAAGCTCCAA-p & Red 705 p-phosphate \\
\hline Ser Sensor & 705-TTGCCTACGCC ACTAGCTCCAA-p & Red 705 p-phosphate \\
\hline Gly wt & 640-TGCCTACGCC ACCAGCTCCAA-p & Red 640 p-phosphate \\
\hline \multirow[t]{2}{*}{ Anchor KRAS } & CGTCCACAAAATGATTCTGAATTAGCTGT & $\mathbf{f}$-fluorscein \\
\hline & ATCGTCAAGGCACT-f & \\
\hline PNA KRAS & TACGCCACCAGCTCC-p & \\
\hline KRAS-for & AAGGCCTGCTGAAAATGACTG & \\
\hline KRAS-rev & GGTCCTGCACCAGTAATATGCA & \\
\hline WT-sequence & GTTGGAGCTGGTGGCGTAGGCAAG Genbank accession no. K01519 & \\
\hline
\end{tabular}



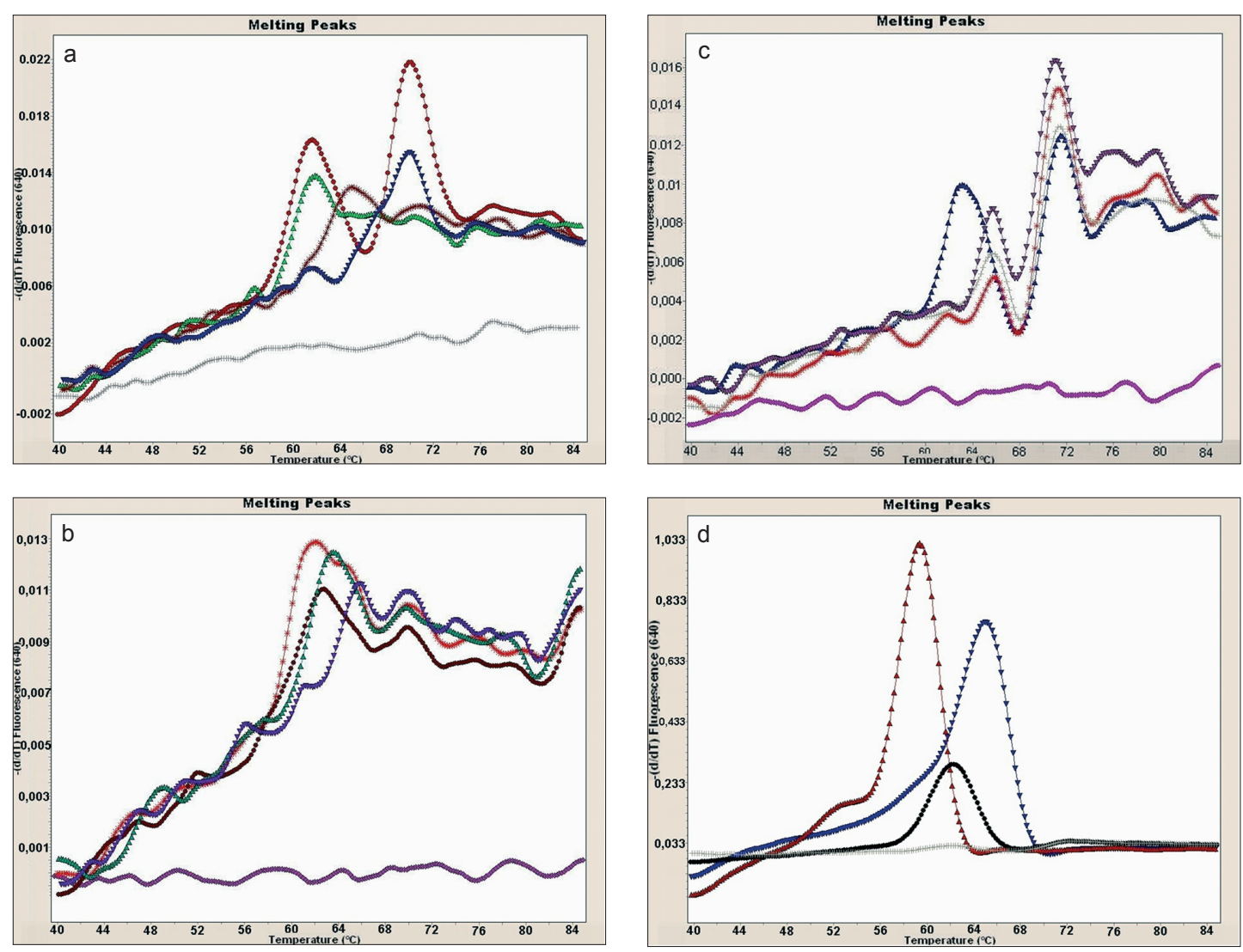

Fig. 1. Melting curves for the detection of $K R A S$ mutation.

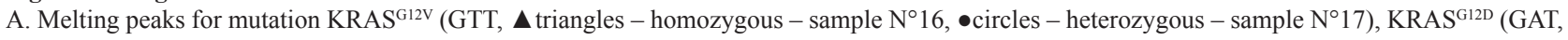
* stars - sample $\mathrm{N}^{\circ} 8$ ), without mutation (GGT, $\mathbf{\nabla}$ down triangles - sample $\left.\mathrm{N}^{\circ} 14\right)$, NTC (+cross - non template control) without of PNA in reaction. B. Peak with $\boldsymbol{\Delta}$ triangles represents sample $\mathrm{N}^{\circ} 29$ with mutation $\mathrm{KRAS}^{\mathrm{G} 12 \mathrm{~A}}(\mathrm{GCT}), \boldsymbol{\nabla}$ down triangles - sample $\mathrm{N}^{\circ} 5$, * stars - sample $\mathrm{N}^{\circ} 31,+$ cross sample $\mathrm{N}^{\circ} 34$ all with mutation $\mathrm{KRAS}^{\mathrm{G} 12 \mathrm{~S}}$ (AGT) respectively, diamonds - NTC, concentration of PNA $0.05 \mu \mathrm{M}$.

C. Peak with $*$ stars represents sample $\mathrm{N}^{\circ} 15$ with mutation $\mathrm{KRAS}^{\mathrm{G} 12 \mathrm{~V}}$, $\bullet$ circles - sample $\mathrm{N}^{\circ} 6$ with mutation $\mathrm{KRAS}^{\mathrm{G} 12 \mathrm{~A}}$, $\boldsymbol{\Delta}$ triangles - sample $\mathrm{N}^{\circ} 25$ with mutation $\mathrm{KRAS}^{\mathrm{G} 12 \mathrm{D}}, \boldsymbol{\nabla}$ down triangles - sample $\mathrm{N}^{\circ} 26$ with mutation $\mathrm{KRAS}^{\mathrm{G} 12 \mathrm{~S}}$, $\bullet$ diamonds $-\mathrm{NTC}$, concentration of PNA $0.15 \mu \mathrm{M}$.

D. Melting peaks for $\operatorname{KRAS}^{\mathrm{G} 12 \mathrm{C}}\left(\mathrm{TGT}, \boldsymbol{\Delta}\right.$ triangles - sample $\left.\mathrm{N}^{\circ} 1\right), \mathrm{KRAS}^{\mathrm{G} 12 \mathrm{D}}\left(\mathrm{GAT}, \boldsymbol{\nabla}\right.$ down triangles - sample $\left.\mathrm{N}^{\circ} 3\right)$, KRAS ${ }^{\mathrm{G} 12 \mathrm{~V}}\left(\mathrm{GTT}\right.$, $\bullet$ circles $-\mathrm{DNA}^{2}$ from cell line SW480), NTC (+ cross - non template control), concentration of PNA $2.5 \mu \mathrm{M}$.
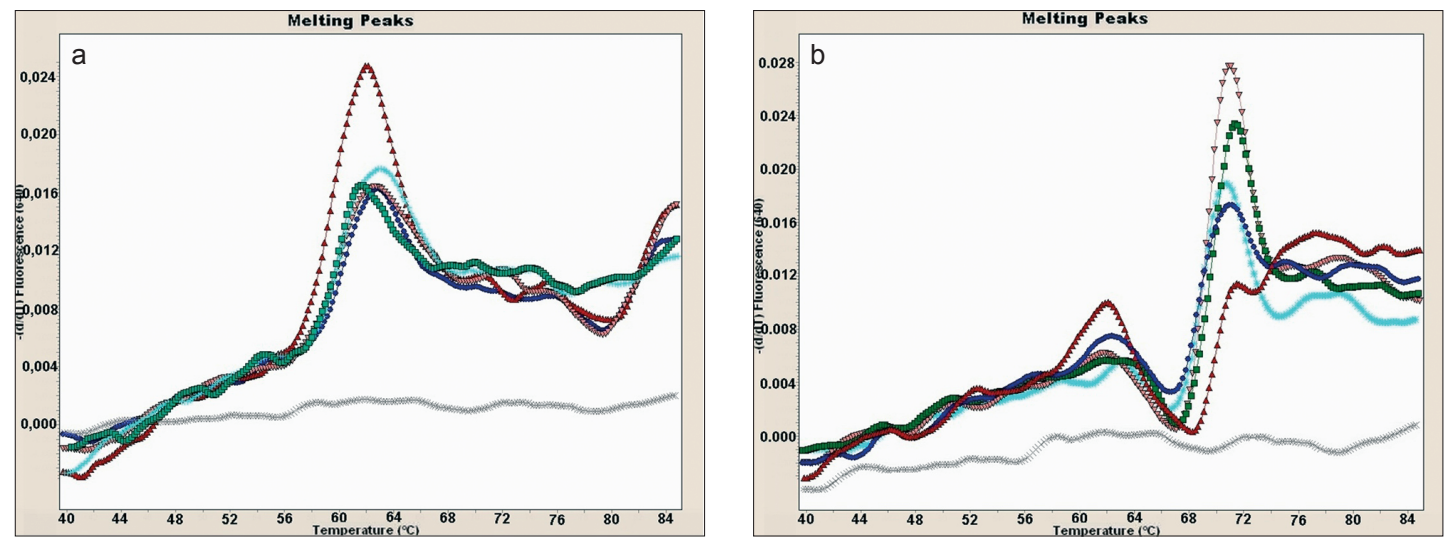

Fig. 2. Comparison of melting curve analysis of samples with $K R A S$ gene mutation.

A. with PNA $(1.5 \mu \mathrm{M})$ in reaction

B. without PNA in reaction

Peaks with $\boldsymbol{\Delta}$ triangles and $\mathbf{m e c t a n g l e s}$ represent samples $\mathrm{N}^{\circ} 32$ and $\mathrm{N}^{\circ} 40$ respectively which contain mutation in KRAS ${ }^{\mathrm{G} 12 \mathrm{~V}}$, peaks with $*$ stars, $\boldsymbol{\nabla}$ down triangles and $\bullet$ circles represent samples $\mathrm{N}^{\circ} 10, \mathrm{~N}^{\circ} 11$ and $\mathrm{N}^{\circ} 28$ respectively which contain mutation $\mathrm{KRAS}^{\mathrm{G} 12 \mathrm{D}}$, NTC ( $\mathrm{X}$ diag cross - non template control). 


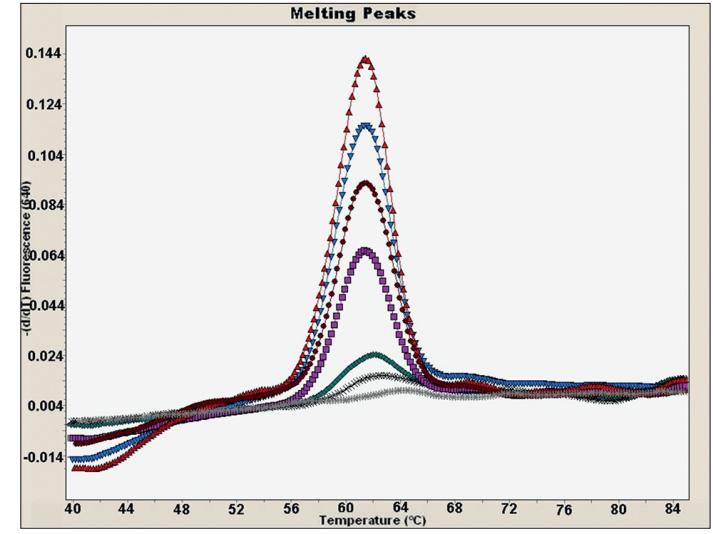

Fig. 3. Assay sensitivity for detection of KRAS mutation in a large excess of wild-type DNA.

Peak with $\mathbf{\Delta}$ triangles represents only mutant DNA, with $\mathbf{\nabla}$ down triangles represents ratio of $1: 10$, $\bullet$ circles $-1: 100$, -rectangles $-1: 1000$, diamond - 1:10000, $\mathbf{x}$ diag cross $-1: 100000$, * stars - NTC. Under the optimal conditions using 12 Val Sensor as the probe and PNA $(2.5 \mu \mathrm{M})$ as the blocker of WT amplification.

\section{Methods}

Clinical samples. Samples were obtained with the patients' permissions after biopsy, endoscopically and by ERCP from 40 individuals: 4 with colorectal carcinoma (CRC), 3 colon polyp (CPo), 5 pancreatic cancer (PC), 8 chronic pancreatitis (CP), 9 biliary duct stenosis (BDS), 8 biliary tract carcinoma (BTC), 3 papillary adenoma (PA) (Tab. 1). DNA from cell line with $K R A S$ gene codon 12 mutation SW480 (G12V) from DSMZ (Braunschweig, Germany) were used as the positive control. DNA from normal human lymphocytes without mutation was used as the negative control.

Nucleic acid extraction. Genomic DNA was extracted from fresh frozen tumor tissue and from body fluids (bile, pancreatic juice, blood) using QIAamp DNA Mini Kit (Qiagen, Hilden, Germany) according to the manufacturer's recommendations.

Real-time PCR method of hybridization probes. The method is based on two adjacent probes. The sequence of the primers, probes and the PNA oligomer (TIB MOLBIOL, Berlin, Germany) are listed in Table 2. The amplification of template DNA (50-100ng) was performed in LightCycler 1.5 Instrument (Roche Applied Science, Mannheim, Germany). Obtained fluorescence data were analyzed using the LightCycler software with "Tm Calling” Analysis mode (software version 4.1, Roche Diagnostics).

Sequence analysis. Detection of mutation was confirmed by direct sequencing of PCR amplicons after PNA-probe assay by using of primers KRAS-for and KRAS-rev (Tab. 2). Sequences were aligned with previously published sequences [The National Center for Biotechnology Information (NCBI) GenBank accession No. M54968].

Assay sensitivity. We tested assay's limits for detection of the trace amount of mutant allele in a large excess of wild-type DNA. Mutant DNA from the homozygous GTT mutant cell line SW480
(MT) was serially diluted with wild-type genomic DNA [wild-type $K R A S$ codon 12 DNA (WT) originated from normal human lymphocytes] to get decreasing ratios of mutant-to-total DNA. $1 \mu \mathrm{g}$ of WT DNA was diluted with $100 \mathrm{ng}, 10 \mathrm{ng}, 1 \mathrm{ng}, 100 \mathrm{pg}, 10 \mathrm{pg}$ of MT DNA. $100 \mathrm{ng}$ of total DNA from each of the diluted samples were used as a template to establish the detection threshold of the method (Fig. 3). The experiment was repeated 3 times.

\section{Results}

We used the method of real-time PCR and the Light-Cycler software for the detection of KRAS alterations by the determination of amplicon $\mathrm{T}_{\mathrm{m}}$ properties depending upon duplex formation and sequence variance. This method requires a specific anchor probes and results in generation of a different $\mathrm{T}_{\mathrm{m}}$ specific for each mutation. We designed probes adjacent to codon 12 for the most common mutations found in GIT malignancies [GAT (KRAS $\left.S^{\mathrm{G} 12 \mathrm{D}}-\mathrm{Asp}\right)$, GTT $\left(K R A S^{\mathrm{G} 12 \mathrm{~V}}-\mathrm{Val}\right), \mathrm{GCT}\left(K R A S^{\mathrm{G} 12 \mathrm{~A}}-\mathrm{Ala}\right), \mathrm{TGT}\left(K R A S^{\mathrm{G} 12 \mathrm{C}}\right.$ - Cys) and AGT (KRAS $S^{\mathrm{G} 12 \mathrm{~S}}$ - Ser)].

Analysis of the sensitivity. To optimize the PCR conditions we used DNA from cell line SW480 (KRAS codon 12 homozygous GTT). We tested various amount of PNA in PCR reaction to suppress amplification of the wild-type DNA (Figs. 1, 2). Lower concentration was inefficient -0.05 and $0.15 \mu \mathrm{M}$ PNA and resulted in a minimal decrease of the wild-type signal (Fig. 1B, 1C). As is shown on the Figure 2, where is comparison of melting curve analysis of the equal samples with KRAS gene mutation - with PNA $(1.5 \mu \mathrm{M})$ in reaction (Fig. $2 \mathrm{~A})$ and without PNA in reaction (Fig. 2B), peaks for particular mutation are more expressive. Optimal concentration of PNA which resulted in complete suppression of wild-type signal was $2.5 \mu \mathrm{M}$ (Fig. 1D), while 1.5 and 2.0 $\mu \mathrm{M}$ of PNA in reaction suppressed significantly amplification of wild-type allele. Genomic mutant DNA SW480 (MT) was serially diluted into wild-type KRAS codon 12 DNA (WT) isolated from normal human lymphocytes to get decreasing ratios of MT : WT DNA (1:10, 1:100, 1:1000, 1:10000, 1:10000). Under the optimal condition (using 12 Val Sensor as the probe and $2.5 \mu \mathrm{M}$ PNA as the blocker of WT amplification) in the assay, the signal from as few as 1 pg mutant DNA in presence of $100 \mathrm{ng}$ wildtype genomic DNA was detected. As is shown in the Figure 3, by using this assay we can detect one mutated cell in access of $10^{5}$ healthy cells.

Genotyping of KRAS mutation in various samples of GIT malignancies. For the testing of our method, we used various clinical samples. Cohort of 40 patients with different diagnosis of GIT disease was examined for the presence of KRAS gene codon 12 mutations. Genotyping was carried on the base of melting temperatures $\left(\mathrm{T}_{\mathrm{m}}\right)$. As is shown in the Tab. 1, the incidence of searched mutations was $27 / 40(67.5 \%)$. We established the point mutation in 3 of $6(50 \%)$ samples from colorectal carcinoma, 2 of $3(66.7 \%)$ samples from colon polyp, 5 of $6(83.3 \%)$ samples from pancreatic carcinoma, 5 of 8 (62.5\%) samples from chronic pancreatitis, 6 of $7(85.7 \%)$ samples from biliary tract carcinoma, 3 of $8(25 \%)$ samples from biliary duct stenosis and 3 of $3(100 \%)$ samples from papillary adenoma (Tab. 3). 
Tab. 3. Incidence of KRAS mutations in samples of different GIT diagnoses.

\begin{tabular}{|c|c|c|c|c|c|c|c|c|c|c|c|c|c|}
\hline \multicolumn{2}{|c|}{ CRC } & \multicolumn{2}{|c|}{ CPo } & \multicolumn{2}{|c|}{$\mathrm{PC}$} & \multicolumn{2}{|c|}{ PAC } & \multicolumn{2}{|c|}{ BTC } & \multicolumn{2}{|c|}{ BDS } & \multicolumn{2}{|c|}{ PA } \\
\hline $\mathrm{N}^{\circ}$ & $\mathrm{Mu}$ & $\mathrm{N}^{\circ}$ & $\mathrm{Mu}$ & $\mathrm{N}^{\circ}$ & $\mathrm{Mu}$ & $\mathrm{N}^{\circ}$ & $\mathrm{Mu}$ & $\mathrm{N}^{\circ}$ & $\mathrm{Mu}$ & $\mathrm{N}^{\circ}$ & $\mathrm{Mu}$ & $\mathrm{N}^{\circ}$ & $\mathrm{Mu}$ \\
\hline 4 & $\mathrm{~A}$ & 1 & $\mathrm{C}$ & 8 & $\mathrm{D}$ & 7 & - & 5 & $S$ & 6 & $\mathrm{~A}$ & 31 & $S$ \\
\hline 29 & A & 2 & - & 11 & D & 9 & - & 10 & $\mathrm{D}$ & 16 & V & 17 & V \\
\hline 30 & - & 3 & D & 14 & - & 15 & V & 12 & - & 18 & - & 26 & S \\
\hline 38 & A & & & 25 & D & 23 & D & 13 & $\mathrm{D}$ & 20 & - & & \\
\hline 39 & - & & & 28 & D & 22 & - & 19 & D & 21 & D & & \\
\hline & & & & 40 & V & 24 & V & 34 & S & 33 & - & & \\
\hline & & & & & & 27 & D & 37 & D & 35 & - & & \\
\hline & & & & & & 32 & V & & & 36 & - & & \\
\hline
\end{tabular}

We determined the interassay variability of the melting temperatures. For $K R A S^{\mathrm{G} 12 \mathrm{C}}, K R A S^{\mathrm{G} 12 \mathrm{~V}}, K R A S^{\mathrm{G} 12 \mathrm{~A}}, K R A S^{\mathrm{G} 12 \mathrm{D}}, K R A S^{\mathrm{G} 12 \mathrm{~S}}$ and wild-type the variability was $59.0^{\circ} \mathrm{C} \pm 0.8(\mathrm{n}=20), 61.5^{\circ} \mathrm{C} \pm 0.8$ $(\mathrm{n}=30), 63.0^{\circ} \mathrm{C} \pm 0.8(\mathrm{n}=15), 64.0^{\circ} \mathrm{C} \pm 0.8 \quad(\mathrm{n}=30), 65.8^{\circ} \mathrm{C} \pm 0.8$ $(\mathrm{n}=30)$ and $71.5^{\circ} \mathrm{C} \pm 0.8(\mathrm{n}=30)$ respectively (Fig. 1,2). Therefore this allows precise discrimination of wild-type and mutant DNA by melting point analysis.

Incidence of the particular type of mutations in our samples was: $K R A S^{\mathrm{G} 12 \mathrm{D}}$ in $12(44.4 \%), K R A S^{\mathrm{G} 12 \mathrm{~V}}$ in $6(22.2 \%), K R A S^{\mathrm{G} 12 \mathrm{~S}}$ in $4(14.8 \%), K R A S^{\mathrm{G} 12 \mathrm{~A}}$ in $4(14.8 \%), K R A S^{\mathrm{G} 12 \mathrm{C}}$ in $1(3.8 \%)$ from all of 27 founded mutations at codon 12 of the KRAS gene. Consequently, the results of mutation testing were confirmed by DNA sequencing of the corresponding fragment of the KRAS gene and the identification of the mutation status of the sample was confirmed with the $100 \%$ accuracy.

\section{Discussion}

The aim of our work was to develop a sensitive procedure for detection of KRAS mutation in codon 12 in various types of clinical samples. In the present study, we tested the multiplex real-time PCR technique using the five hybridization probes labeled with an acceptor fluorochrome (at the 3' end) and probe labeled with a donor fluorochrome (LightCycler system). In general, the proportion of malignant or premalignant to normal cells in clinical samples is extremely low. To increase the detection of a minimal amount of mutant DNA we used the peptide-nucleic-acid (PNA) oligomers. In contrast to work of Däbritz et al (31), where was a wild-type PNA (17-mer) and mutant-specific fluorescent-labeled hybridization probe for one mutation used, we used the 15-mer wild-type PNA and five mutant-specific fluorescent-labeled hybridization probes, which include more frequent codon 12 KRAS mutation. For this reason, all alleles with single base changes can be easily distinguished from wild-type by melting peak analysis. Recently several studies were done (29), (30), (28), in which was a similar PCR technique used with fluorescent hybridization probes and competing peptide nucleic acid oligomers to detect KRAS mutations. Detection and discrimination of present mutation from the wild-type allele was determined by the melting point temperature $\left(\mathrm{T}_{\mathrm{m}}\right)$ shift. We could assign the particular mutation only approximately, because the melting points $\left(\mathrm{T}_{\mathrm{m}}\right)$ were in close vicinity in our case. In spite of this incidence, the particular type of mutations in our samples corresponds with findings in literature (4).
The determination of difference between samples with and without mutation is undoubted (Fig. 1). The sequencing results showed $100 \%$ concordance with genotyping by our method.

Sampling is very important for objective estimation of the point mutation. The most frequent source of sample for analysis is i.e. paraffin embedded tissue. It was shown, that it is useful as well to collect blood samples before treatment and to combine blood tests with others (31). Also, the testing for the presence of mutant KRAS in stool has been proposed for the detection of pancreatic and colorectal carcinoma $(32,33)$. Some studies mentioned other samples like bile or pancreatic juice $(34,13,29)$. Detection of $K R A S$ mutation in pancreatic juice alone is considered insufficient for discriminating between pancreatic cancer and benign diseases (35). In our work we used nine samples obtained after colonoscopy and other 31 were originated from ERCP examination. We confirmed that also bile and pancreatic juice are suitable as samples for genotyping. The frequency of mutations observed in our samples (Tab. 3) was similar to the frequency determined by other researchers (5). The advantage of our assay was that the detection of mutation was accomplished in a single tube on LightCycler without having to go through several laborious procedures including electrophoresis, hybridization and enzymatic reaction.

Numbers of potential biomarkers including mutational activation of $K R A S$ oncogenes are continually investigated as predictors of therapy response. Moreover, KRAS mutation plays an important role in the response rate of anti-EGFR antibodies treatment in patients with metastatic colorectal cancer $(36,37,38,10)$. Several recent studies have shown that patients with KRAS mutations in codons 12 or 13 in metastatic tumors do not benefit from antiEGFR therapy (with cetuximab or panitumumab) $(39,40,41,42)$. In many case it can help to prevent from death of patient.

Finally, we can conclude that this method can be adapted for synchronic detection of multiple mutations and after readjustment by other type mutations may be a useful clinical tool for analyzing $K R A S$ point mutation in various clinical samples. Identification of $K R A S$ mutations is another powerful tool in CRC and pancreatic cancer diagnostic and this method shows a great promise as a molecular biomarker to assign chemopreventive strategies.

\section{References}

1. Hruban RH, Goggins M, Parsons J et al. Progression model for pancreatic cancer. Clin Cancer Res 2000; 6 (8): 2969-2972. 
2. Deramaudt T, Rustgi AK. Mutant KRAS in the initiation of pancreatic cancer. Biochim Biophys Acta 2005; 1756 (2): 97-101.

3. Castagnola P, Giaretti W. Mutant KRAS, chromosomal instability and prognosis in colorectal cancer. Biochim Biophys Acta 2005; 1756 (2): 115-125.

4. Slebos RJ, Hoppin JA, Tolbert PE et al. K-ras and p53 in pancreatic cancer: association with medical history, histopathology, and environmental exposures in a population-based study. Cancer Epidemiol Biomarkers Prev 2000; 9 (11): 1223-1232.

5. Bazan V, Migliavacca M, Zanna I et al. Specific codon $13 \mathrm{~K}$-ras mutations are predictive of clinical outcome in colorectal cancer patients, whereas codon $12 \mathrm{~K}$-ras mutations are associated with mucinous histotype. Ann Oncol 2002; 13 (9): 1438-1446.

6. Monticone M, Biollo E, Maffei M et al. Gene expression deregulation by KRAS G12D and G12V in a BRAF V600E context. Mol Cancer 2008; 7: 92 .

7. Al-Mulla F, Milner-White EJ, Going JJ et al. Structural differences between valine-12 and aspartate-12 Ras proteins may modify carcinoma aggression. J Pathol 1999; 187 (4): 433-438.

8. Russo A, Bazan V, Agnese V et al. Prognostic and predictive factors in colorectal cancer: Kirsten Ras in CRC (RASCAL) and TP53CRC collaborative studies. Ann Oncol 2005; 16 Suppl 4: iv44-49.

9. Winder T, Scheithauer W, Lang A. K-ras mutations and cetuximab in colorectal cancer. N Engl J Med 2009; 360 (8): 834-835; author reply 835-836.

10. van Krieken JH, Jung A, Kirchner T et al. KRAS mutation testing for predicting response to anti-EGFR therapy for colorectal carcinoma: proposal for an European quality assurance program. Virchows Arch 2008; 453 (5): 417-431.

11. Minamoto T, Mai M, Ronai Z. K-ras mutation: early detection in molecular diagnosis and risk assessment of colorectal, pancreas, and lung cancers-a review. Cancer Detect Prev 2000; 24 (1): 1-12.

12. Rothschild CB, Brewer CS, Loggie B et al. Detection of colorectal cancer K-ras mutations using a simplified oligonucleotide ligation assay. J Immunol Methods 1997; 206 (1-2): 11-19.

13. Fischer C, Buthe J, Nollau $P$ et al. Enrichment of mutant KRAS alleles in pancreatic juice by subtractive iterative polymerase chain reaction. Lab Invest 2001; 81 (6): 827-831.

14. Ward R, Hawkins N, O'Grady R et al. Restriction endonucleasemediated selective polymerase chain reaction: a novel assay for the detection of K-ras mutations in clinical samples. Am J Pathol 1998; 153 (2): 373-379.

15. Fuery CJ, Impey HL, Roberts NJ et al. Detection of rare mutant alleles by restriction endonuclease-mediated selective-PCR: assay design and optimization. Clin Chem 2000; 46 (5): 620-624.

16. Ugorcakova J, Hlavaty T, Babal $\mathbf{P}$ et al. Assay design and optimization of mutant-enriched PCR based method for detection of K-ras gene mutations in pancreatic carcinoma. Neoplasma 2006; 53 (5): 363-371.

17. Haug U, Hillebrand T, Bendzko $P$ et al. Mutant-enriched PCR and allele-specific hybridization reaction to detect K-ras mutations in stool DNA: high prevalence in a large sample of older adults. Clin Chem 2007; 53 (4): 787-790.

18. Zhu D, Xing D, Tang $Y$ et al. A novel mutant allele specific amplification and electrochemiluminescence method for the detection of point mutation in clinical samples. Biosens Bioelectron 2009; 24 (11): 3306-3310.
19. Langaee T, Ronaghi M. Genetic variation analyses by Pyrosequencing. Mutat Res 2005; 573 (1-2): 96-102.

20. Poehlmann A, Kuester D, Meyer F et al. K-ras mutation detection in colorectal cancer using the Pyrosequencing technique. Pathol Res Pract 2007; 203 (7): 489-497.

21. Chang YS, Yeh KT, Chang TJ et al. Fast simultaneous detection of K-RAS mutations in colorectal cancer. BMC Cancer 2009; 9: 179.

22. Bernard PS, Wittwer CT. Real-time PCR technology for cancer diagnostics. Clin Chem 2002; 48 (8): 1178-1185.

23. Amicarelli G, Shehi E, Makrigiorgos GM et al. FLAG assay as a novel method for real-time signal generation during PCR: application to detection and genotyping of KRAS codon 12 mutations. Nucleic Acids Res 2007; 35 (19): e131.

24. Gilje B, Heikkila R, Oltedal S et al. High-fidelity DNA polymerase enhances the sensitivity of a peptide nucleic acid clamp PCR assay for K-ras mutations. J Mol Diagn 2008; 10 (4): 325-331.

25. Morlan J, Baker J, Sinicropi D. Mutation detection by real-time PCR: a simple, robust and highly selective method. PLoS One 2009; 4 (2): e4584.

26. Hu Y, Le Leu RK, Young GP. Detection of K-ras mutations in azoxymethane-induced aberrant crypt foci in mice using LNA-mediated realtime PCR clamping and mutant-specific probes. Mutat Res 2009; 677 (1-2): 27-32.

27. Orum H, Nielsen PE, Egholm $M$ et al. Single base pair mutation analysis by PNA directed PCR clamping. Nucleic Acids Res 1993; 21 (23): 5332-5336.

28. Beau-Faller M, Legrain M, Voegeli AC et al. Detection of K-Ras mutations in tumour samples of patients with non-small cell lung cancer using PNA-mediated PCR clamping. Br J Cancer 2009; 100 (6): 985-992.

29. Chen CY, Shiesh SC, Wu SJ. Rapid detection of K-ras mutations in bile by peptide nucleic acid-mediated PCR clamping and melting curve analysis: comparison with restriction fragment length polymorphism analysis. Clin Chem 2004; 50 (3): 481-489.

30. Taback B, Bilchik AJ, Saha $S$ et al. Peptide nucleic acid clamp PCR: a novel K-ras mutation detection assay for colorectal cancer micrometastases in lymph nodes. Int J Cancer 2004; 111 (3): 409-414.

31. Dabritz J, Hanfler J, Preston R et al. Detection of Ki-ras mutations in tissue and plasma samples of patients with pancreatic cancer using PNA-mediated PCR clamping and hybridisation probes. Br J Cancer 2005; 92 (2): 405-412.

32. Koga Y, Yasunaga M, Moriya $Y$ et al. Detection of the DNA point mutation of colorectal cancer cells isolated from feces stored under different conditions. Jpn J Clin Oncol 2009; 39 (1): 62-69.

33. Haug U, Wente MN, Seiler CM et al. Stool testing for the early detection of pancreatic cancer: rationale and current evidence. Expert Rev Mol Diagn 2008; 8 (6): 753-9.

34. Tateishi K, Tada M, Yamagata M et al. High proportion of mutant K-ras gene in pancreatic juice of patients with pancreatic cystic lesions. Gut 1999; 45 (5): 737-740.

35. Futakawa N, Kimura W, Yamagata $\mathbf{S}$ et al. Significance of K-ras mutation and CEA level in pancreatic juice in the diagnosis of pancreatic cancer. J Hepatobiliary Pancreat Surg 2000; 7 (1): 63-71.

36. Amado RG, Wolf M, Peeters $M$ et al. Wild-type KRAS is required for panitumumab efficacy in patients with metastatic colorectal cancer. J Clin Oncol 2008; 26 (10): 1626-1634. 
37. Karapetis CS, Khambata-Ford S, Jonker DJ et al. K-ras mutations and benefit from cetuximab in advanced colorectal cancer. N Engl J Med 2008; 359 (17): 1757-1765.

38. Heinemann V, Stintzing S, Kirchner T et al. Clinical relevance of EGFR- and KRAS-status in colorectal cancer patients treated with monoclonal antibodies directed against the EGFR. Cancer Treat Rev 2009; 35 (3): 262-271.

39. Monzon FA, Ogino S, Hammond ME et al. The role of KRAS mutation testing in the management of patients with metastatic colorectal cancer. Arch Pathol Lab Med 2009; 133 (10): 1600-1606.
40. Allegra CJ, Jessup JM, Somerfield MR et al. American Society of Clinical Oncology provisional clinical opinion: testing for KRAS gene mutations in patients with metastatic colorectal carcinoma to predict response to anti-epidermal growth factor receptor monoclonal antibody therapy. $\mathrm{J}$ Clin Oncol 2009; 27 (12): 2091-2096.

41. Saif MW, Shah M. K-ras mutations in colorectal cancer: a practice changing discovery. Clin Adv Hematol Oncol 2009; 7 (1): 45-53, 64.

42. Fakih MM. KRAS mutation screening in colorectal cancer: From paper to practice. Clin Colorectal Cancer; 9 (1): 22-30.

Received September 10, 2010. Accepted December 18, 2011. 